\title{
Information Searching Pattern of Children With Special Needs (ABK): Background, Starters and Electoral Processes Information Needs
}

\author{
Lutfi Khoerunnisa, Pawit M Yusup, Ute Lies Siti Khadijah \\ Universitas Padjadjaran \\ Khoerunnisa.lutfi@yahoo.com
}

\begin{abstract}
The research was based on the fact that students with disabilities who enroll in primary school inclusion also have a need for an update. This study focused information search process conducted by students with special needs that refer to the information search process theory advanced by Khultau, namely: initiation, selection, exploration, formulation, collection and presentation. The method used in this study was a qualitative research method with a form of case study and test the validity of the data using triangulation techniques. The data collection is done by observation nonpartisipatory, in-depth interviews and document analysis. Informants in this study were students with disabilities in elementary school with the mother of pearl inclusion ABK ingkatan being, so that they can communicate in both directions. The results of this study indicated that information search patterns illustrated through stages that are performed by students with special needs. However, in the process, students with special needs still require guidance, assistance and supervision of assistant teachers and parents.
\end{abstract}

Keywords-- Information Seeking Behavior, Khultau Theory, Children with Special Needs

\section{INTRODUCTION}

Elementary School (SD) Mutiara Bunda is one of the schools with an inclusive model of Islamic education concept. Inclusive schools are schools that implement the system learn to understand the differences that exist around, that every neighborhood and every person has the nature, culture, abilities and backgrounds are different and that difference is the medium of learning. Students are required to understand and adapt to all these differences to foster tolerance and to take lessons from it. In addition, students are not only equipped with the academic knowledge, but also equipped with the values of life.

Children with special needs by Heward (in Amin, 1995) is a child with special characteristics that are different from the majority of children without always pointed to the inability of mental, emotional or physical. Children with Special Needs (ABK) is another term to replace the word Exceptional Children (ALB), which indicates the particular disorder that has different characteristics from one another (Delphie, 2006).

The need and the search is a concept that can not be separated significantly (Suwanto, 1997). Someone will do an activity to meet the need for the information he wants to these needs can terpenihi well, this activity commonly referred to information retrieval. Chen (in Laloo, 2000) states that the search for information is one's activities undertaken to obtain the information it needs. Humans will show the information search behavior to meet their needs.

Seeking information behavior begins when a person feels that there is a knowledge that he possessed when it was less than the knowledge they need. To meet the needs of someone seeking information by using various sources of information. The act of using literature is a behavior that in fact describe a variety of purposes (Krikelas in Suwanto, 1997).

According Khultau (1991) describes the information search activities as a construction (building development) through which someone from the stage of uncertainty (uncertainty) towards comprehension (understanding). Khultau also stated there are six things to consider for searching information, among other things Initiation, is when someone for the first time care will be needed knowledge, feel unsure and anxious about something. This is because they are aware of their information needs.

\section{METHODS}

In this study the authors used qualitative research methods. As the format of research to find, collect, process and analyze the research data. Qualitative research methods as a research procedure that produces the data descriptive form of words written or spoken of people and observed behavior (Bogdan \& Taylor in Moleong, 2011).

While the shape of this research is a case study. The case study is an in-depth study of the events, environments and situations that allow express or understand one thing (Basuki, 2006). 
Sulistiyo-Basuki mention that the observations can be useful in the early stages of planning the research project (2006, p. 148). Meanwhile, Hadi Sutrisni the Sugiyono (2010) stated that the observation is a complex process, a process that is composed of a variety of biological and psychological processes (Sugiyono, 2010, p. 145).

\section{FINDING AND DISCUSSION}

Overall, students with special needs in SD Mutiara Bunda searching for a dilator background information by the interest of the students towards something they like, the task of the teacher and to satisfy their curiosity is high. In addition to the general lessons learned in school such as natural science, social science, mathematics, Indonesian, they also learn the English language skills of their interest.
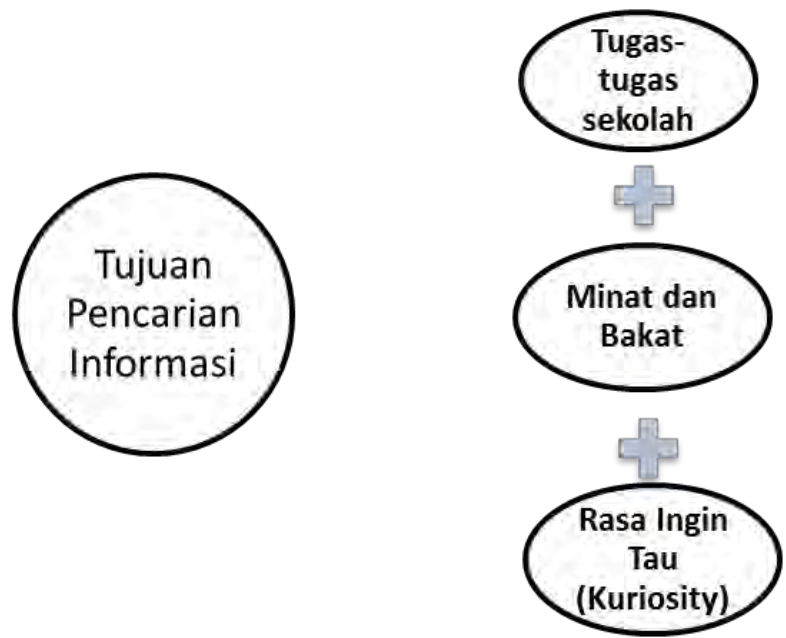

Figure 1 Interest Information Search ABK students

Interest is something that they enjoy, outside of school. And the skills they gained in the USA or a special class called Child Stimulation Unit. Some skills Among them, music, sports, horseback riding, drawing, singing, playing music and much more. Based on interviews revealed that they enjoy such interest is art, drawing, sports, social sciences, natural sciences and mathematics.

It is also in line with the opinions Krech, Crutchfield and Ballachey (in Yusup, 1995: 8) states that the need for information is a condition that occurs where a person feels there is a vacuum of information or knowledge as a result of a task or just curiosity.

\section{a. Starter Phase}

Early stage is the stage when someone for the first time will be the knowledge needed care. Researchers understand if the beginning of the search for information is a condition where a person has a sense of want to know about something because one is aware of their information needs.

The initial step in an information retrieval is the introduction to know and understand what information is needed. From the introduction phase, knowledge of the understanding of that information will form the stages of information retrieval. In this phase, researchers in identifying the initiation conducted by special needs students to search information. The researchers asked how the beginning of students with disabilities to search information, whether they deliberately write needs the information they need or they will find information in accordance with what is wanted them to know. And from the process of observation, before seeking information, informants mostly just remember just get what he needed.

In the early stages, most often done by students with disabilities in elementary school Mother of Pearl is, they always remember information about what they need. This is because some students with special needs have a very strong memory. They are accustomed to a new pattern, so that they can remember all the sequence and detailed, enough with the ability to remember them sharp. 


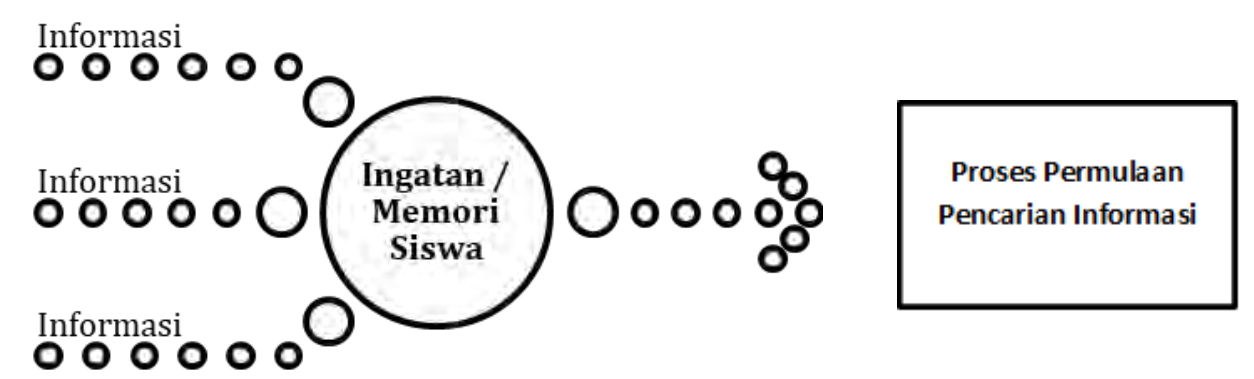

Figure 2 Based Startup Process Memoryof the Students

From the perspective of the researcher, that children with special needs before searching for information, then given the information that they need to look for then automatically they will try to remember and find the information, certainly because they have a sense of curiosity is very high and they feel they need to know.

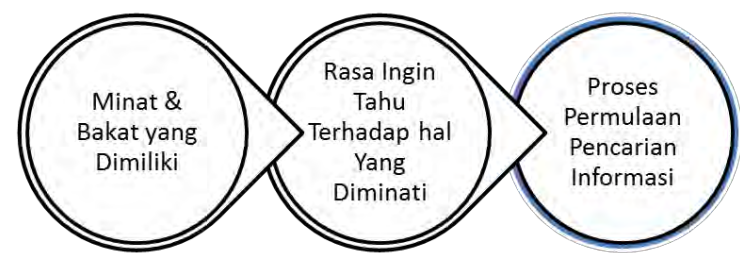

Figure 3 Process Starts Interest Based Information Search

Other start-up process triggered by the task-yugas they get in school. In this case, they will reopen the task notes they wrote in school, then do a search for information related to the tasks that they need.

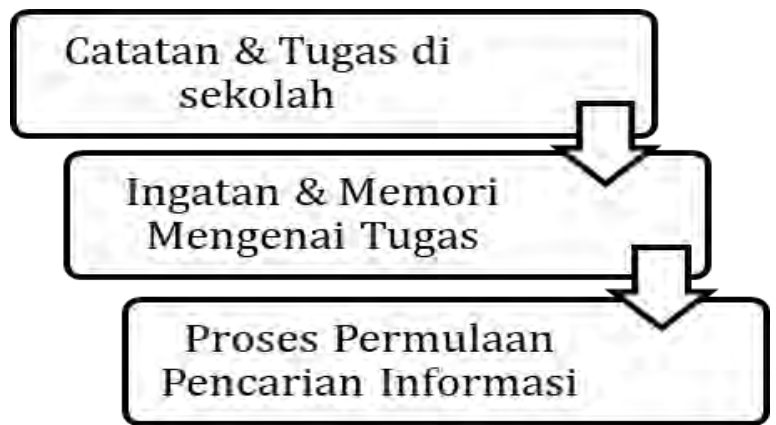

Figure 4 Startup Process Task Based Information Search

The beginning of the process undertaken by the student prior to searching information that are based on their needs in meeting their information needs. Overall, students with special needs are always observing something first, and then if they're interested or curious, then they will look for information that makes them want to know it, and most of them are interested in information or a thing in accordance with the interest and interest them.If depicted in a pattern, Starters process information search conducted by students with disabilities are as follows: 


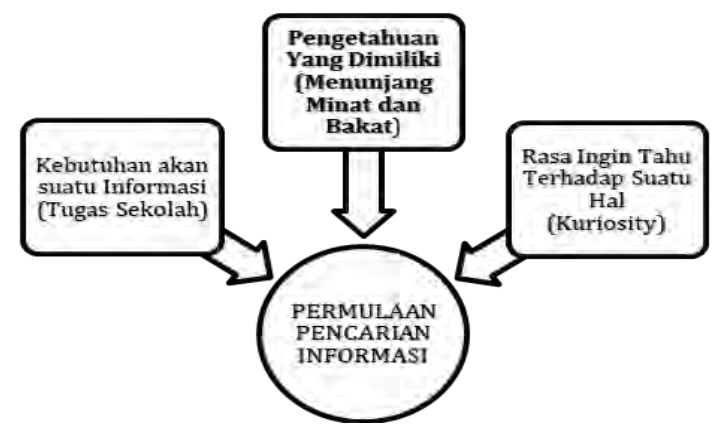

Figure 5 Starters process of information retrieval

\section{b. Selecting Phase}

Selection is the process of identifying a common topic. At this stage, students with special needs tend to be more concerned with information relating to the tasks of the school and information about their interests and talents. Special needs children are in need of assistance in the process of information retrieval. Not that they could not do what they need, but most of them tend to have not been able to determine and differentiate between information that is they need, where the information is appropriate for them and where that information is not appropriate.

A. Type 1 (Very Requires Assistance)

In this type, special needs students tend not able to choose the content information according to their needs. Students Special bekebutuhan one type of a student with special needs category of medium and heavy. They are in need of assistance in the process of finding the information they need. And the role of parents or teachers very important role to help direct and inform about the information that is appropriate to their needs, either at home or at school.

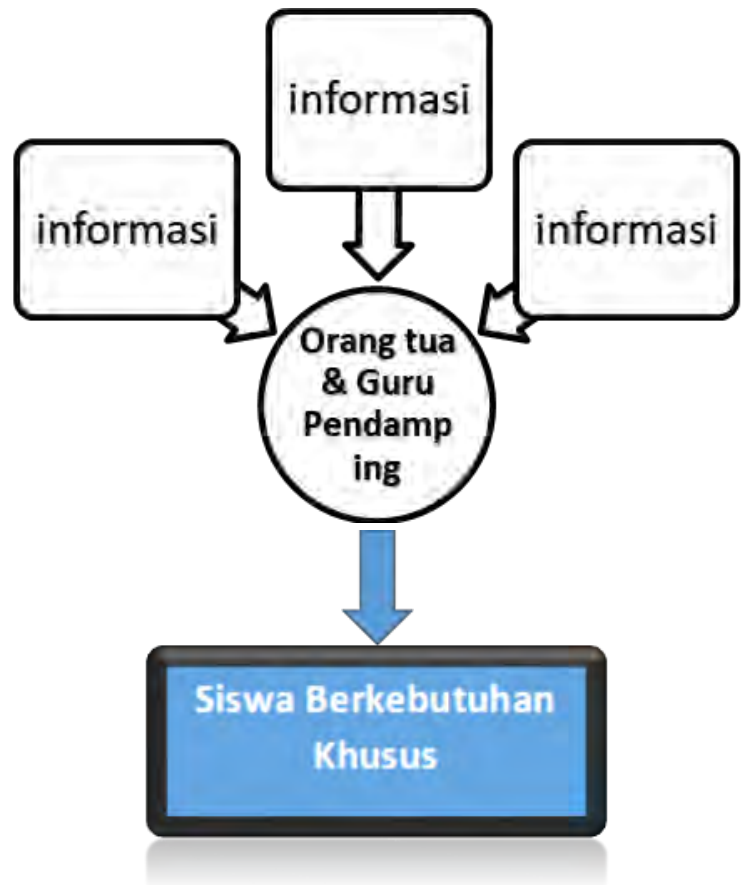

Figure 6 Type One in the information search process

A simple example is that writers get in the field, when one of the students with special needs with the initials $\mathrm{AV}$, who was following the citizenship lessons suddenly issued a harsh word to friends who were beside him. When asked why AV AV did it turn out just listening to her talk about something less good, AV does not filter the received information that his talks melainkah respond directly. AV can not distinguish where the information should be taken and which information is not good to take. Another example is $\mathrm{ZN}$, a child with autism high category, which is often said and acted arbitrarily, so also in the process of information retrieval, $\mathrm{ZN}$ still need guidance from parents and teacher assistant at the school. 


\section{B. Type 2}

Unlike the AV, several other students with disabilities tend to be more active and more understanding toward infrmasi content they are looking for, they can make the selection of information according to their needs.

In this second type, students with special needs does not mean it does not require the help of a teacher or a parent, but they just need assistance and supervision only. That is, they have the ability to pick and choose which information they need and that is the appropriate information, and good for them.

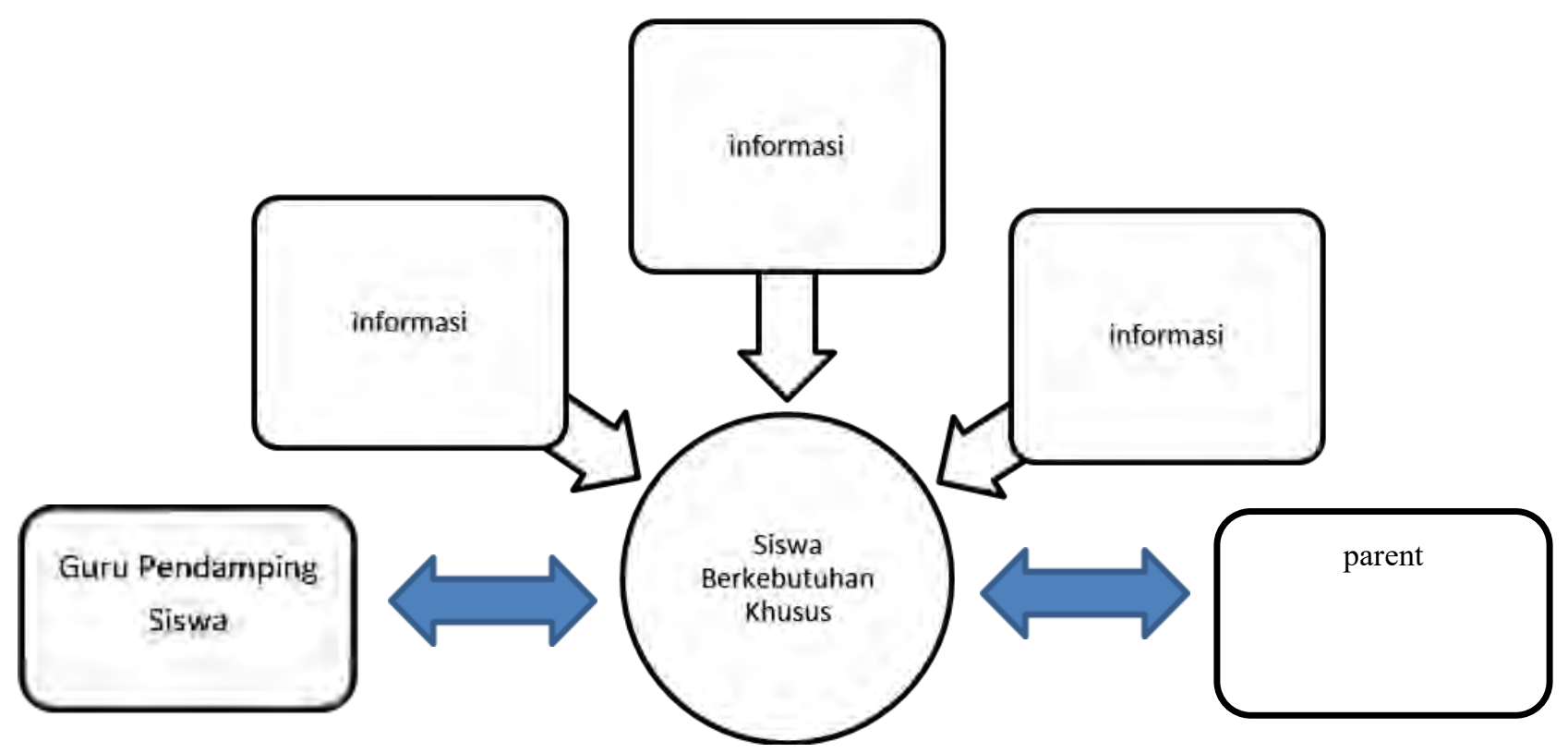

Figure 7 Second mode in the process of Search Information

From these results it can be concluded that there are some students with special needs who is in need of assistance in some of the information seeking process, there are also special needs students who can choose and make the selection of the needs of the information they seek. In the interview process, there are some students with special needs are indeed very need assistance continuously. This applies to students with special needs with a high level.

\section{CONCLUSION AND RECOMMENDATION}

The conclusion derived from the analysis of the results of this study, namely:

1.Background information search conducted by students with disabilities in elementary school inclusion mother of pearl is to meet the needs of the students in completing the tasks given by the teacher at school and to meet the needs of information related to their interests and talents.

2.In the process of Starters, special needs students to search information based on what they need. Students with special needs only to remember just what they are looking for information, except for information relating to the task, there are some of those who write them.

3. The selection process is done by some students with special needs still require assistance, because most of them do not yet have the ability to filter the information they receive. Nevertheless, most of them have been able to perform well enough information selection.

\section{Reference}

Armstrong

(2005).

Multiple

Intellegences.

Electronic

Files

contained

in

http://www.thomasamrmstrong.com/multiple intelegences.htm accessed on 10 September 2015

Assia, D. (2015). Impact of Educational Inclusion Learning Patterns Against Children with Special Needs.

$\begin{array}{lllll}\text { Electronic Journal of } & \text { University } & \text { of }\end{array}$
Cirebon.http://web.iaincirebon.ac.id/ebook/repository/DEWI\%20ASIYAH_141062 10006_ok.pdf $(12 / 13 / 2015)$.

Baihaqi \& Sugiarmin. (2014). Understanding and helping children with ADHD. Bandung: Refika Aditama.

Basuki, S. (2006). Metode penelitian. Jakarta: Wedatama Widya Sastra.

Delphie, B. (2012). Child learning: An introduction inclusion in education. Bandung: Refika Aditama

Gardner, H., \& T. Hatch. Educational Theory of Educational. Reasearcher, 18 (Nov. 1989). Pg 410.http://www.jstor.org/stable/1176460 (8/12/2015). 
Harisanty, D. (2009). Information Needs and High School Students Availability of Resources in High School Library in Surabaya, Surabaya: Electronic Journals http://palimpsest.fisip.unair.ac.id/images/pdf/Dessy.pdf (7/12/2015).

Jhonshon, BH. Special educational needs book 1. Bandung: Indonesian Education University Graduate Program. Khultau, CC. (1991). "Inside the reaserch process: Information Seeking From the User's Perspective." Journal of the American society form information science. 42 (5). p. 361-371 (11/9/2015).

Laloo, BT. (2002). Information needs, seeking information behavior and users, New Delhi: Ess Ess Publication.

Moleong, LJ. (2007). Peneltian kualitatif: Metodologi. Bandung: Teens Rosdakarya.

Mulyana, D. (2001). Qualitative research methods: A new paradigm communication sciences and other social sciences. Bandung: Youth Rosdakarya.

Pendit, PL. (2003). Library and information science research: An introduction discussion and deals with the means and methodology. Jakarta: MPS-FSUI.

Praptiningrum, N. (2010). Implementation of Inclusive Education Phenomenon for Children with Special Needs, $\begin{array}{llllll}\text { Journal of } & \text { Special } & \text { Education } & 7 & \text { (2). } & \text { November }\end{array} 2010$. http://journal.uny.ac.id/index.php/jpk/article/view/774 .pdf (12/16/2015)

Rakmat, J. (1997). Metode penelitian komunikasi. Bandung: Remaja Rosdakarya

Sugiyono. (2008). Metode penelitian pendidikan:(pendekatan kuantitatif, kualitatif dan $R$ \& D). Bandung: Alfabeta.

Yusup, P. M. (1995). Pedoman praktis mencari informasi. Bandung: Remaja Rosdakarya.

Yusup, P. M., \& Subekti, P. (2010). Teori dan praktik penelusuran informasi: information retrieval. Kencana Prenada Media Group.

Yusup, P. M. (2009). Ilmu informasi, komunikasi, dan kepustakaan. PT Bumi Aksara. 